\title{
Merits And Demerits of Araling Panlipunan (Social Studies) Teachers in Using Instructional Resources
}

\author{
VENY ROSE GARCIA-ACOJIDO*
}

San Vicente Elementary School,San Pablo, Isabela Philippines

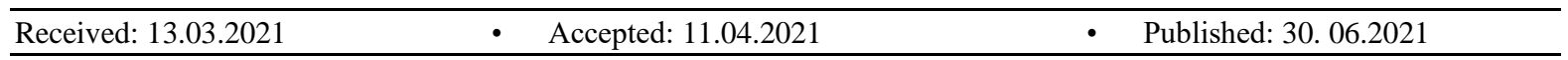

\begin{abstract}
The study elucidates the merits and demerits or strengths and weaknesses in using the instructional resources among Social Studies teachers. In the Basic Education Unit of the Department of Education, this study would give them feedback on how and what interventions would be the best to employ and reinforce to overcome their weaknesses. This study used the descriptive method of research to determine the strengths and weaknesses of teachers in teaching Araling Panlipunan ( Social Studies). The study focused mainly on the strengths and weaknesses of teachers in teaching Araling Panlipunan( Social Studies) in terms of teaching content, motivating the students, presenting the lesson, assessing student performance, and attainment of lesson objectives. Data were gathered from the Grade IV teachers who handled Araling Panlipunan ( Social Studies) subject during the study and their respective pupils in San Pablo, Isabela.

The performance of the Grade IV pupils was determined in terms of their final grades in Araling Panlipunan ( Social Studies) during the School year 2017-2018 and through their percentage score in a forty-item achievement test. With these strategies, the teacher frees the students to learn using their critical thinking abilities so that they will be able to discuss crucial issues and challenges that confront them in everyday life.
\end{abstract}

Keywords: merits, demerits, instructional resources, Araling Panlipunan ( Social Studies)

\section{Introduction}

Araling Panlipunan (Social Studies) is a course of study that focuses on human connections and how society functions. It is a portion of a school curriculum that includes classes in history, government, economics, civics, sociology, geography, and anthropology and is focused on the study of social relationships and the functioning of society.

For a variety of reasons, teaching Araling Panlipunan may be considered and seen as a significant benefit to an educator. Being an Araling Panlipunan teacher comes with several benefits, which, when considered, can provide a great deal of inspiration and motivation to those who want to pursue a career in this field. The following may be an advantage of teaching Araling Panlipunan: an educator may gain a world discovery by teaching Araling Panlipunan. The Araling Panlipunan instructor's responsibility is to use literature and technology to gain a background and thorough understanding of various countries throughout the world (Legazpi, 2017).

\footnotetext{
* Corresponding Author: venyrose.acojido@deped.gov.ph
} 
Teaching Araling Panlipunan, or Social Studies education, should go beyond the essentials and include learning experiences enriched by the use of appropriate tactics and resources that meet the students' potentials and instructional capacities. Because Social Science instruction and learning necessitates a high level of thinking, it should be designed and presented to achieve specific goals, one of which is to increase learners' performance.

Araling Panlipunan is commonly taken from the first year to the fourth year of high school in the old Basic Education Curriculum. In Grades I to III, it was called as Sibika at Kultura and in Grade IV to VI; it was HEKASI or Heograpiya at Kasaysayan at Sibika. With the implementation of the K to 12 Basic Education Program, Araling Panlipunan is already in Grades I to VI. The curriculum for Grade IV focused its study on the following: YUNIT I: Ang Aking Bansa, YUNIT II: Lipunan, Kultura, At Ekonomiya Ng Aking Bansa, YUNIT III: Ang Pamamahala Sa Aking Bansa at YUNIT IV: Ako Sa Pag-unlad Ng Aking Bansa. The study of Araling Panlipunan in basic education is integral in the development of pupils, whom the government envisions to become socially aware, actively involved in public and civic affairs, and contribute to the development of a progressive, just, and humane society. A teacher has a significant role to play in developing the pupils' interest in studying the subject. This means that a teacher is a facilitator of learning this subject. For this reason, the fundamental purpose of the study is to elucidate the merits and demerits of teachers in teaching Social Studies using instructional resources.

\section{Literature Review}

\subsection{Social Studies Education}

In order to obtain comprehensive information related to this study, a number of literature and related studies are presented in this research.

Materials, according to Allright (1990), should teach students how to learn, serve as a resource book for ideas and activities for instruction/learning, and provide teachers with rationales for what they do. According to O'Neil (1990), materials may be acceptable for students' needs even if they are not especially developed for them. Textbooks help students review and prepare their courses, textbooks are time and money efficient, and textbooks can and should allow for adaptation and improvisation.

According to Littlejohn and Windeatt (1989), materials include a hidden curriculum that comprises attitudes toward knowledge, attitudes toward teaching and learning, attitudes toward the teacherstudent relationship, and values and attitudes connected to gender, society, and so on.

Performance evaluations that contain evidence from real teaching practice may be able to provide a more direct assessment of teaching abilities. Furthermore, these assessments can provide information to programs concerning areas of strength and weakness in their graduates' preparation for the goal of improving the program and, in turn, contributing to the improvement of teacher quality.

Teachers must respect the diversity and complexity of their students' race, gender, culture, language ability, and interests in the classroom. Carag (2020) is a word that comes to mind. All of these factors play a role in getting pupils to work and learn in class. As previously said, what happens in the classroom is determined by the teacher's ability to keep students' attention. As a result, teachers play a critical role in bringing about changes in the classroom. "Teaching takes occur only when learning 
takes place," wrote the Educator's Diary in 1995. Students are motivated to learn if the teacher's teaching style is appropriate for the class and is applied regularly. 12 The teachers, according to Maria Theresa Barberos et al., are the central figure.

Teachers aren't defined by a single set of attributes. "Teachers don't have a cookie-cutter template," Britt explains. "Knowing your strengths is the most important thing." From class planning through instruction, trust who you are as a teacher and let it shape your experience. "When instructors use their skills in the classroom, they are more naturally involved with their students, and students notice!" says Carol Vernon, a certified executive coach with Communication Matters.

Kristin Gregory, a senior strengths consultant, states, "Our greatest chance for large and rapid development rests in our strengths." Naturally, as a teacher, you interact with a wide range of personalities. And your personality may conflict with that of one of your students at some point. "It's important to remember that you're dealing with human beings who are learning and growing," Britt adds, "so you might need to alter your style so that you can help all learners." It's also critical to be adaptable and modify as necessary, regardless of your natural strengths. "Students who push you," Britt says, "provide you a fantastic opportunity to grow and change." "The first step in learning more about your strengths is to get to know yourself. "A strong sense of self is necessary for good teaching," Britt argues. Make a list of the tasks that thrill you (they're likely the ones that get ticked off first on your to-do list), as well as the ones that you consider drudgery. Take notes on what other teachers have said about how you teach. Do they make comments about your organization, humor, or inventiveness, for example?

Teachers are thought to be the bright spots in the classroom. Learning is easier when kids are motivated, according to Bangayan-Manera (2019). Motivating kids to learn, on the other hand, is a difficult task for the teacher. To pique pupils' interest, it takes a range of teaching approaches or techniques. Motivating kids to learn, on the other hand, is a difficult task for the teacher. Cambria says it takes a range of teaching styles or techniques to pique kids' interests.

Above all, the teacher must acquire a sufficient understanding of the curriculum's objectives and standards and teaching skills, interests, appreciation, and ideals. Galiza and Alonzo (2021). He or she must make an attempt to guide youngsters or pupils into a wide, full, exciting, and satisfying existence. While some students appear to be naturally enthusiastic about learning, many others require or expect their instructors or teachers to motivate, challenge, or stimulate them "In order for students to learn effectively in the classroom, the teacher must be able to maintain the interest that drew them to the course in the first place (Erickson, 1978; Pema Dendup, 2020; Jamoom \& AlOmrani , 2021).

\subsection{Conceptual Framework of the Study}

It has always been said that the role of the teacher in the classroom is multidimensional. He/she guides pupils apart from teaching; she is the manager, adviser and facilitator of classroom activities by providing opportunities for them to think critically and try various ways of doing but not forgetting that teachers have different strengths and weaknesses in their teaching strategy. Teachers' methods and practices inside the classroom directly influence how pupils acquire knowledge and understanding.

Identifying the strengths and weaknesses of teachers in teaching Araling Panlipunan enhances the teaching-learning process. Analyzing these variables can foster teachers' abilities 
and lessen or eradicate weaknesses resulting in the pupils' improved academic performance in Araling Panlipunan subject.

\section{Methodology}

\subsection{Research Design}

This study used the descriptive method of research to determine the strengths and weaknesses of teachers in teaching Araling Panlipunan, the instructional materials which they used, their teaching prctices and the academic performance of the pupils in the said subject.

\subsection{Respondents of the Study}

The respondents of the study were the twelve (12) Grade IV public elementary school teachers handling Araling Panlipunan and their respective pupils in San Pablo District, San Pablo, Isabela. They were chosen as respondents because they are teaching Araling Panlipunan subject. The schools include: Simanu Norte Elementary School, Ballacayu Elementary School, Caralucud Primary School, Auitan Elementary School, San Jose Elementary School, Binguang Elementary School, Bungad Elementary School, Minanga Elementary School, Calamagui Elementary School, Annanuman Elementary School, San Vicente Elementary School, and Dalena Elementary School.

The researcher used stratified random sampling in selecting the 104 respondents from the total population of two hundred thirty-four (234) pupils. The colored popsicle strategy was used wherein pupils who picked up colored popsicles from the box were the 17 pupil-respondents of the study. The number of colored popsicles was based on the predetermined sample size which is $30 \%$ of the total number of pupils in every class. However, total enumeration was applied to classes with very few pupils. In determining the performance of the pupils-respondents, their final grades were obtained from their respective class advisers. Although, the achievement test was administered to all of the pupils, only the raw scores of the pupil-respondents were analyzed.

\subsection{Data Gathering Procedure}

The questionnaire was distributed to the Grade IV Araling Panlipunan teachers and to the pupilrespondents and retrieved by the researcher herself. The achievement test was personally administered by the researcher to the pupil-respondents in the twelve (12) schools of San Pablo District after the scheduled Fourth Quarter examination

\subsection{Data Gathering Instrument}

The major tool used in gathering data in this study was a survey questionnaire. The questionnaire consisted of items to elicit information on the strengths and weaknesses of teachers in teaching Araling Panlipunan in terms of teaching content, motivating the pupils, presenting the lessons, assessing pupils' performance, and attainment of objectives. The researcher adapted the questionnaire on motivational statements and teaching practices of teachers from the Teaching Learning Observation Chart (TLOC) Inclosure to DECS Order No. 74, s. 1991 of San Pablo District.

A forty-item multiple-choice achievement test in Araling Panlipunan covering Quarters 1 to 4 was taken from the Teacher's Guide and Curriculum Guide. 18 


\section{Data Analysis}

To describe the information gathered in the study, frequency, percentage, and the arithmetic mean were used. To determine the relationship between the pupils' performance in Araling Panlipunan and their perception on teachers' practices in teaching the subject, the Kendall's Tau Coefficient of Correlation was used, employing the R-studio, version 3.5.1. Kendall's Tau Coefficient was used because the variable, teaching practices, is at the ordinal level of measurement and its interpretation is very direct. The hypotheses were tested at 0.05 level of significance. A P-value greater than 0.05 means that the Kendall's Tau Coefficient of Correlation is not significant. In other words, there is no significant relationship between variables.

\section{Results And Discussion}

\subsection{Merits and demerits of Teachers in Terms of Teaching Content}

The strengths and weaknesses of teachers in terms of content in Quarter 1 are shown in table 1. It shows that all teachers (100\%) covered Topics 1 to 8, a good start for the school year.The specific topics are: Ang Pilipinas ay Isang Bansa, Ang Kinalalagyan ng Pilipinas, Ang Teritoryo ng Pilipinas, Ang Pilipinas ay Bansang Tropikal, Mga Salik na may Kinalaman sa Klima ng Bansa, Ang Kinalaman ng Klima sa mga Uri ng Pananim at Hayop sa Pilipinas, Ang Pilipinas bilang Isang Bansang Insular, Mga Pangunahing Anyong Lupa at Anyong Tubig sa Bansa. Furthermore, Topics 9 to 12 are considered strengths of the teachers since almost all of them $(91.67 \%)$ covered the said topics. This means that only one of them did not cover Topics 9 to $14(8.33 \%)$. In view of the 20 teachers' responses, it can be said that in the first quarter of the school year, their strengths are all the topics except for one of them who did not cover the last six topics.

On the other hand, the majority of the pupils responded positively, that is, at least 71 out of 104 pupils and at most 100 pupils said that all the topics were taught by the teachers, as supported by the percentage shown in Table $2(68.27 \%$ and 96.15\%). However, the pupils also revealed that the teachers have weaknesses as some of them did not cover the topics $(3.85 \%)$. Their greatest weakness is Topic 7 (31.73\%) followed by Topic 13 (22.12\%) and the lowest are Topics 1 and 8 (3.85\%).

The strengths and weaknesses of teachers in teaching Araling Panlipunan during Quarter 2 are based on their responses shown in table 3 which revealed that all teachers $(100 \%)$ said that they covered Topics 2, 3, 5 and 7 while eleven of them (91.67\%) 23 covered Topics 4, 6, 9 to 12, 14, 16 and 17. Ten of them (83.33\%) covered Topics 1, 8, 13 and 15; and eight of them (66.67\%) covered Topic 18. This means that some of them did not cover Topics 4, 6, 9 to 12, 14, 16 and 17 (8.33\%); Topics 1,8 and $15(16.67 \%)$ and Topic $18(33.33 \%)$. In view of the teachers' responses, it can be said that their strengths are all the topics except for some of them who are weak on some of the topics.

Quarter 3. The strengths and weaknesses of teachers in teaching Araling Panlipunan based on their responses on the topics in Quarter 3 are shown in table 5. According to table 5, all teachers (100\%) said that they covered Topics 2, 3 and 6 while eleven of them (91.67\%) covered Topics 4, 5, 7 to 14. Ten of them $(83.33 \%)$ covered Topic 1 , and 9 of them (75.00\%) covered Topic 15 . This means that 
some of them did not cover Topics 4, 5, 7 to 14 (8.33\%); Topic 1 (16.67\%) and Topic $3(25.00 \%)$. In view of the teachers' responses, it can be said that their strengths are all the topics except for some of them who are weak on some of the topics. Table 6 shows the pupils' responses on the topics in Quarter 3. The table reveals that majority of the pupils responded positively that is, at least 78 pupils and at most 101 pupils said that all the topics were taught by the teachers, as supported by the frequencies shown in Table $6(75.00 \%, 97.16 \%)$. However, the pupils also revealed that the teachers have weaknesses as some of them did not cover the topics $(32.88 \%, 25.00 \%)$. Their greatest weakness is Topic14 (25.00\%) followed by Topic 15 (20.19\%). Quarter 4 The strengths and weaknesses of teachers in teaching Araling Panlipunan based on their responses on the topics in Quarter 3 are shown in table 7. According to table 7, all teachers (100\%) said that they covered Topics 3, 5 and 7 while eleven of them (91.67\%) covered Topics 1, 2, 4, 6, 8 and 9.Ten of them $(83.33 \%)$ covered Topic 10 and eight of them $(66.67 \%)$ covered topic 11 . This means that some of them did not cover Topics 1, 2, 4, 6, 8 and 9 (8.33\%); Topic 10 (16.67\%) and Topic $11(33.33 \%)$. In view of the teachers' responses, it can be said that their strengths are all the topics except for few of them who are weak on some of the topics.

\subsection{Teachers' Strengths and Weaknesses in Presenting the Lesson}

The teachers' responses regarding their strengths and weaknesses in presenting lessons are shown in tables 11 and 12, respectively. Some teachers pointed out that their strength in presenting lessons lies on the use of pictures and other visual presentations like jigsaw, puzzle, jumbled letters and other visual presentations $(41.67 \%)$. Only one of them cited strength on presenting the lesson by letting pupils watch a video, use of powerpoint through Youtube, Google or multi-media applied to their level or IQ, reviewing the previous lesson before presenting the new lesson, explaining the objectives well and presenting a story related to the lesson, presenting the lesson with motivating questions and collecting the ideas of pupils about the topic, relating or connecting the lesson to the life-experiences of the learners, and presenting an actual situation.

\section{Conclusion}

The findings of the study led to the following conclusions:

1. The teachers in Araling Panlipunan or Social Studies have strengths in teaching content, motivating pupils, presenting lessons, assessing pupils' performance, and attaining teaching objectives.

2. The teachers are trying hard to cope with educational challenges with the use of varied instructional aids/ resources.

\subsection{Recommendations}

In the light of the findings of the study, the researcher offers the following recommendations:

1. Teachers who are weak in the classroom management in terms of teaching content, motivating pupils, presenting the lessons, assessing pupils' performance and attainment of objectives must be motivated to attend relevant trainings and pursue postgraduate studies not only for personal reasons but more for professional growth and enhancement of transfer of learning. 
2. Education supervisors and schools heads must utilize data on teachers' need $\mathrm{s}$ in designing training matrices in order to improve teachers' competence.

\section{References}

[1] Alonzo E. \& Galiza C. ( 2021). Writing prowess of first year BAT students: A groundwork for language magnification program. The Asian EFL. 28(13), 39-49

[2] Bangayan- Manera (2019). Doodle: A Hermeneutical Appreciation in Jacques Derrida's Deconstruction. The Asian EFL Journal. 24(4), pp.191-204.

[3] Cambri Jr, A. A. (2021). The Sequel of VDOCS On the Magnification of Learners in Identifying the Tenets of Political Ideologies. Psychology and Education Journal, 58(2), 7972-7976. https://doi.org/10.17762/pae.v58i2.3399

[4] Carag, E (2020). Pedagogical Approaches used by teachers in MAPEH in the Division of Tuguegarao City, Philippines. International Journal of Psychosocial Rehabilitation.24.(8).

[5] Galiza, C. (2021). Needs to survive in Writing: A comparative analysis. The Asian EFL Journal. 28 pp.6377

[6] Jamoom, O., \& Al-Omrani , M. . (2021). EFL University Teachers' Engagement in Research: Reasons and Obstacles. International Journal of Linguistics and Translation Studies, 2(1), 135-146. https://doi.org/10.36892/ijlts.v2i1.121

[7] Mitchelle T. et al. (2001). Why People Stay Using Job Embeddedness to Predict Voluntary Turnover. The Academy of Management Journal. 44(6).

[8] Pema Dendup. (2020). The Beliefs and Practices of Bhutanese English Teachers in Teaching Grammar in English as a Second Language (ESL) Classroom in Bhutan. International Journal of Linguistics and Translation Studies, 1(2), 84-99. https://doi.org/10.36892/ijlts.v1i2.32 